This item was submitted to Loughborough's Research Repository by the author.

Items in Figshare are protected by copyright, with all rights reserved, unless otherwise indicated.

\title{
The intermediate time of news consumption
}

\section{PLEASE CITE THE PUBLISHED VERSION}

http://dx.doi.org/10.1177/1464884916689155

\section{PUBLISHER}

SAGE $\odot$ The Author(s)

\section{VERSION}

AM (Accepted Manuscript)

\section{PUBLISHER STATEMENT}

This work is made available according to the conditions of the Creative Commons Attribution-NonCommercialNoDerivatives 4.0 International (CC BY-NC-ND 4.0) licence. Full details of this licence are available at: https://creativecommons.org/licenses/by-nc-nd/4.0/

\section{LICENCE}

CC BY-NC-ND 4.0

\section{REPOSITORY RECORD}

Keightley, Emily, and John Downey. 2017. "The Intermediate Time of News Consumption”. Loughborough University. https://hdl.handle.net/2134/24941. 


\section{The Intermediate Time of News Consumption.}

\section{Introduction}

Many accounts of contemporary mediated communication of various kinds emphasise speed, immediacy and simultaneity as overriding temporal characteristics, ${ }^{1}$ and accounts of journalism are no exception. While journalism has always placed a premium on speed (Phillips 2011), it has become commonplace to talk of the continued acceleration of news production and circulation as leading to a dearth of time for journalistic analysis and resulting in uncomfortable alliances between the 'frenetic and the banal' in the 'breathless routine' of the news day (Lewis and Cushion 2009: 316). Acceleration in journalistic practice and the associated changes in news content and its communication have a variety of consequences. In the most extreme accounts, this produces evershallower news content while the immediacy of its delivery collapses deliberative time for its interpretation.

This article attempts to challenge some of the assumptions on which these assertions are based by taking an alternative starting point in analysing news time and temporality: the news audience. We begin by arguing that many accounts which emphasise the paralysing effects of fast communication and the acceleration of news in particular fail to acknowledge the complexities of news consumption, instead pessimistically reading off the effects of speed from communications technologies themselves. We go on to consider the value of social scientific audience research characterisation of practices of consuming the news in contemporary culture and suggest that these need to be accompanied by ethnographic approaches to the audience which engage with the ways in which meaning is produced from the resources that journalism provides in everyday lived contexts. Adopting this approach reveals the limited explanatory value of acceleration and speed when considering the news audience and their temporal experiences of news consumption. We use the concept of 'intermediacy' to illustrate how the temporalities of news are actively produced through the synthesis of multiple times in situated instances of reading, viewing or listening to the news, and 
that this opens up the possibility for very different valuations of the news consumption. We use two qualitative examples to show how the intermediate time of news is produced. The examples that we have chosen demonstrate the complex temporal contexts in which news is consumed, which comprise a variety of media and communications texts and technologies. Our examples prominently feature television and radio as vehicles of news delivery as the project from which this data is drawn demonstrated that analogue media, or at least digital versions of older analogue technologies, remain very much a part of the temporal ecology of news consumption. ${ }^{1}$ As we discuss below the emergence of digital technologies has complicated the temporalities of news consumption, contributing the pluralising and mobilising of opportunities for engaging with news. However the temporal complexities intrinsic to the consumption of mediated news are far from new, nor are they the sole preserve of digital news consumption. Understanding the temporalities of contemporary news consumption requires exploring everyday practices which can and do rove across and between digital and analogue modes of consumption. Using our empirical examples we demonstrate that if the multiple times that are in play when we consume the news are acknowledged then speed as an overriding temporal logic in any given instance is called into question.

\section{Fast and Slow News}

The social, cultural and political consequences of speed have been considered in detail by Paul Virilio (1986, 1995). For Virilio, the compression of time-space created by the invention and diffusion of new technologies, including media technologies, has had a direct impact on social and political life. He claims, for example, in relation to the 1994 media coup of Berlusconi, the dictatorship of speed results in the dictatorship of a media tycoon. What is striking here is that new media technologies are seen as the primary cause of public political disorientation, 'a shock, a

\footnotetext{
${ }^{1}$ For further discussion of relations between the analogue/digital shift in practices of media use but in relation to photography, see Keightley and Pickering (2014) for a discussion of the continuing salience of analogue technologies and practices based on this same body of research data.
} 
mental concussion' to use Virilio's phrase (1995). The election of Berlusconi is seen as evidence of this mental concussion on the part of the public. Subsequently Jean Chesneaux took up this theme of 'our modern obsession with speed' (2000: 408). He also uses the example of Berlusconi and his frustration at the slowness of Italian politics in comparison to the much more desirable high speed of business life. For Chesneaux, however, democracy requires time. Indeed, the complex character of modern societies means that we need more time for debate, consultation, deliberation and decision-making. Thus the speed of new technologies and the public's obsession with speed rubs up against democratic procedures and norms conjuring up dystopian images of authoritarian populist leaders and ignorant and easily manipulated publics bound together by the real time of media technologies. In a manner similar to Virilio's original article we are presented with a causal path which runs from new technologies to elites 'addicted to speed' (2000: 412) to government by opinion poll by politicians eager to take short cuts with democratic procedure. New technologies have begotten a generalised culture of valorisation of speed, of publics caught in the here and now of 'real time', untethered from history, a sense of the past and of the future. This more general and philosophical argument about technology, time and democracy has been taken up in the study of news journalism and its publics.

The most comprehensive and insightful analysis of 'real time news' i.e. live, continuous coverage of events has been conducted by Lewis, Cushion and Thomas (2005) in their study of 24 hour news channels in the UK. Such channels have led to a shift, they claim, in the raison d'etre of journalism away from the scoop to immediacy, 'the thirst for "breaking news" '(2005: 466). The focus of their discussion is the 'role of news channels in a society' (2005: 462), whether these channels help or hinder citizens in making sense of the world and acting politically. Do the 24 news channels, for example, provide more analysis and context to help citizens make sense of events (2005: 464)? Lewis et al discover that these news channels do provide more 'live', 'real-time' news than traditional news programmes but most of the time this liveness is of a rather mundane sort of 
the studio anchor talking with a reporter on location and they conclude that this produces a 'feeling of "liveness"' giving the audience a sense of being "right there, right now" (2005:465, emphasis in original). The vast majority of news stories covered on these channels are not breaking news but rather a repetition of news stories, rolling bulletins and live two-ways. There is also a great deal of on air 'hanging around' waiting for scheduled news events such as news conferences to happen. Our problem here is not with the analysis of the fabrication and dramatification of 'liveness' as a genre of news reporting but with the assumptions that it makes about audiences and their interpretation of what is placed before them. The fabrication of liveness is 'insidious' in that it causes harm gradually in that it 'favours spectatorship over investigation' (2005:468). The audience are placed in the subject position of spectators with little attempt to enhance their understanding of events through the provision of analysis and context. In a sense the audience are seen as victims of the news, it 'leaves most viewers none the wiser, and, in all probability, rather bored' (2005:475). The immediacy of the news actually serves then to slow down the audience's subjective sense of time. The point here is not to take issue with the empirical analysis of the form and content of news channels but to raise concerns about how this is supposed to affect the audience. For Virilio, the real-time creates a disorientated, shocked and mentally concussed audience susceptible to demagogues. For Lewis et al we have an imagined majority audience as inattentive, uninterested and ill-informed, a lamentable product of contemporary technologically-enhanced journalism.

The antidote to fast news is seen as slow news, drawing on the successful marketing work of Slow Food campaigners in Italy (Le Masurier, 2015). There are some difficulties with this concept. Inauthentic fast news is challenged by authentic slow-storytelling and slow news values. The danger here is that we forget in our counter-valorisation of slowness that slow news is produced, created and manufactured and overlook the need to interrogate notions such as 'quality journalism'. Le Masurier asks rhetorically 'Might a slower approach to journalism with its emphasis on quality, pleasure, storytelling and a focus on what matters to particular communities be one way to engage a 
distracted, overloaded, disinterested (sic) audience?' (2015:148). Ironically, what Virilio, Lewis et al and Le Masurier share is their speed in drawing inferences from the speed-up of news to broad generalisations of its negative effects on audience beliefs and behaviour. Real time news variously disorients, concusses, distracts, bores its audience. It disturbs the audience's sense of time and throws it out of its ideal engaged and attentive state but these conclusions are drawn or assumed without an analysis of the actual audience and their contexts.

While the intentional speeding up of communications technology is clearly part of a wider technological acceleration which has had far reaching effects on social reality, it remains unclear what the role of the human subject in the construction and experience of mediated time actually involves. So, while acknowledging that contemporary journalism is undoubtedly marked by the increasing speeds of information transfer, as it has been since the technological developments of the printing press and telegraph, some of the assumptions that are routinely made about the temporal experience of news consumption require interrogation and the tendency to read off audience disengagement from the temporal logics of fast journalism and news content need challenging. How, in practice, are 'imperfect humans' (Hassan 2007: 51) navigating the temporal terrain of journalism?

\section{Approaching the News Audience.}

In journalism studies, the news audience remains the poor relation both as an empirical and theoretical object (Peters 2012: 704). Empirical research which accounts for the consequences of fast communication for news audiences' experiences of time and kinds of social and political relations that they facilitate remain particularly elusive. The modest body of social scientific research that does attend to the news audience has busied itself with producing quantitative accounts of audience behaviours ranging from degrees of exposure to news content to the patterns in the 
adoption of new technologies for accessing the news. The resulting analyses have demonstrated that the acceleration of content production and increasing immediacy in the delivery of news have supported wide-ranging changes in the news consumption patterns.

In recent years the shift of audiences away from traditional print and broadcast news to online platforms has been a major preoccupation for journalism studies but recent research has revealed the continued dominance of television and print media (Ahlers 2006; Papathanassopoulos et al 2013) with relatively recent European audience statistics positioning television as the most important source of news (Eurobarometer 2009). The resilience of television as a source of news has given rise to investigations of the informational quality of 24 hour broadcast news and 'live' reporting (Cushion 2015; Huxford 2007) and have, alongside older concerns over the speed of televisual flows of information (Williams 1992) and its relentless characteristic 'nowness' (Doane 2001: 274), contributed to a persisting sense that these temporal features undermine audience attention and engagement with substantive news content. Alongside this, in 2013 more than half of Europeans claimed to use the Internet for cultural purposes, and three in ten did so at least once a week (Eurobarometer 2013). The rise of the internet-enabled mobile device has precipitated a significant shift in news consumption practices. The 2014 Reuters Institute Digital News Report states that 'The use of smartphones and tablets has jumped significantly in the past year, with fewer people using their computers for news. More than a third of online news users across all countries (39\%) use two or more digital devices each week for news and a fifth $(20 \%)$ now say the mobile phone is their primary access point' and these increases in smartphone and tablet usage are cited as 'driving more frequent access to news and from more locations' (Reuters Institute 2014). This has led to a decline in the spatial, but more significantly for our purposes, temporal "context stability" of news consumption (Westlund 2015); we consume the news anytime, anywhere. 
The resilience of traditional news media alongside the rise of the online and mobile forms of consumption has led to the characterisation of the news audience as "inherently cross-media" (Schrøder 2011). News consumption comprises of complex intertwined practices of media use which are more 'seamless and blurred, hybrid and complex than they used to be" (Bjur et al. 2014, 15). The rise of online 'access anytime, anywhere' news has not necessarily ushered in a new and intensified climate of news consumption that many media scholars would see as conducive to an informed electorate and vibrant civic society. While the majority of adults in the UK (95\%) say they follow the news and television remains far the most-used platform for news, with $75 \%$ of UK adults saying they use TV as a source of news (Ofcom 2014: 1) there are significant concerns around the efficacy of self-reporting methodologies in relation to news consumption leading to gross exaggeration of the size of the news audience (Prior 2009). In addition, in a multichannel, multimedia context it is increasingly easy to actively avoid news content and although there is a variable impact across Europe and the US, increases in TV exposure in Europe during the last decade have 'reduced the time citizens spend watching news and programmes about politics and current affairs' (Aalberg et al 2013: 17; see also Prior 2009; Ksiazek et al 2010). Predictors of whether people are news avoiders or consumers have become increasingly complex with 'individual-level characteristics such as socioeconomic status and political interest [...] becoming more important as predictors of news consumption in a rapidly changing media environment (Shehata and Strömbäck 2011: 110). This increasingly differentiated perspective on the audience is closely connected to concerns that a multimedia, multichannel environment has provided the conditions for audience fragmentation, so as 'more offerings are delivered on broadband networks and more choices are available "on-demand," patterns of consumption become more widely distributed' (Webster and Ksiazek 2012: 39). This distributed audience has been heralded as ushering in a pluralised cultural space but without the necessary interaction between specialised audience clusters (Tewkesbury 2005; Sunstein 2007, McQuail 1997) to sustain a healthy civic communication. As a result, it has been argued that the contemporary news audience can be characterised as 'porously bordered 
groups of people who know something about specific parts of the social world but perhaps little else' (Tewkesbury 2005:333; see also Chaffee and Metzger 2001). The simultaneity of plural forms of news alongside entertainment content is considered to have an 'alienating' (Rosa 2008) effect on the audience. It would seem that audience research confirms that changing temporal structures of journalism brought about by technological changes have a direct impact on the audience causing declining consumption, fragmentation and instability. Although speed, immediacy and their negative consequences have not gone unchallenged in accounts of the temporalities of news consumption, most critiques have hinged on audience's desire for slower time in-depth news analysis as well as fast, up-to-the minute headlines (e.g. Philips 2012) This goes at least part way to reversing the dominance of acceleration in our understanding of news consumption by recognising the audience's role in the production of temporality. Nevertheless, challenges of this kind remain reliant on a notion of linear speed. The dichotomy of fast and slow remains and the lived temporalities of news consumption are not fully explored; simply recognising other slower temporal 'rates' is insufficient to allow the complex times of news consumption to be addressed. Other modes of time, such as historical time and duration, are also implicated in the contexts of consumption or the meanings that we make from news content. Failure to recognise these complexities means that solutions to the 'problems' of acceleration are continually sought in the realm of news production and dissemination without fully recognising that 'representations of time and space arise out of the world of social practices' (Harvey 1997: 212) and that fast communication of news is not the only social practice in play. It is perhaps understandable that in a context where consumption practices are so distributed, seeming to occur anytime, anywhere, more readily identifiable and accessible changes in news and journalism itself is consistently used as the entry point or template for analyses of audience experiences. Nevertheless, the explanatory power of this approach is seriously limited if we want to explain the temporalities that are sustained in a contemporary news environment. As Tomlinson cautions, media technologies do not determine 
time and our experience of it: 'we risk delusion if we cannot view this influence in reasonable relation to [...] other aspects of experience (2007: 97; see also Keightley 2013).

In seeking out an approach to the news audience which affords the possibility of seeing time as produced through news consumption and its manifold social dimensions, we follow Bird (2010) and Madianou (2008; 2010) in adopting ethnographically-informed approaches which consider 'what people do and say around and about media' (Bird 2010: 417). For Bird this involves conceiving news as 'a cultural form, a social phenomenon and institution' (2010: 430). Of course cultural approaches to the uses of media are not new. Research on the 'domestication' of media technologies has explored the ways in which technologies are used and actively made meaningful in everyday life (e.g. Berker et al 2006, Silverstone and Hirsch 1992; Silverstone 1994; Sorensen 1994; Sorensen et al 2000; Haddon 2005). This has included how technologies can be used to navigate and manage the temporal conditions and challenges of contemporary social and cultural life (e.g. Nansen et al 2009). Domestication studies have illustrated that temporal experience can be understood as produced through our reciprocal interactions with media technologies and forms in the continual movement between their temporal affordances and our navigation of them. However, when considering how time is produced through news consumption an emphasis on ritual, practice and social action form only takes us so far. News is a category of media content and so the symbolic construction of time within it and the ways in which these are creatively interpreted and made sense of by a news audience across a range of contexts of consumption is a crucial constituent of temporal experiences. ${ }^{2}$ It is not simply when and how we consume the news that contributes to audience's sense of time, but also how we imaginatively engage with different social and experiential times that it represents to us in various ways.

\footnotetext{
${ }^{2}$ See Keightley 2013 for an extended discussion of domestication literature and its value in understanding the production and experience of mediated time.
} 
While social scientific research on the news audience reveals the extent to which news consumption can be conceived as structured by the temporal logics of multiple media, cultural approaches provide empirical tools for understanding how the temporalities of news consumption are imaginatively, socially and culturally produced in everyday encounters with the news. By using the latter as a starting point the sections that follow consider how, imaginatively and through practice, time is produced as an experiential quality in the processes of consuming the news, what kinds of temporalities are produced through these processes.

\section{The intermediate audience}

Paul Ricoeur (1985/1988) has conceptualised an historical mode of time which exists between lived (or psychological time) and universal (or physical) time, and is produced through ongoing cultural mediation between them. Human temporal experience is produced in the cultural articulations which characterise this 'between' time. Ricoeur considers the role of various cultural tools in its production such as calendars and clocks through which our phenomenological personal time and abstract time of the physical world are synthesised into culturally meaningful temporalities. While news media are not discussed directly by Ricoeur we can consider news as a communicative tool which contributes to the production of this cultural mode of time. This shifts our analytic focus beyond the intrinsic logics of news as a temporal tool and onto the way in which the news is continually involved in the active synthesis of phenomenological and abstract forms of time. News time is a therefore a socio-cultural process rather than a pre-given attribute. This cultural mode of time is irreducibly social, folding together private and public modes of time using cultural tools to allow time to be shared and communicated: the time of others is thus always implicated in it and brought into relation with our own. This shared time can be constructed through the symbolic content of the news and its communicative structure, for example we share in a common sense of dailyness or liveness alongside collective senses of public time encoded in news narratives and 
marked out by the reporting of public events. By beginning an analysis of the temporalities of news consumption by attending to the multiple mediated, experiential and physical times which characterise the contexts in which news is consumed, we can reopen a consideration of news media and content as constituent elements of a region of temporal difference and plurality.

Understanding temporality as manifold times has been most comprehensively conceptualised by Barbara Adam in her work on 'timescapes' $(1998 ; 2004)$ which she developed in order to 'understand relationships, interdependencies and embeddedness' of the constituents of social time (2008: 4). Using this heuristic for understanding the multiple contexts and features involved in the production of social time and situating the temporal logics of media (the time of technologies, genre/form and media content) within it as part of the process of its production draws us away from characterising the time of news consumption as fast or slow, deliberative or inattentive, but rather as 'a liminal condition which opens up at the juncture of different temporal modes, rhythms or representations' (Keightley, 2013: 67). Sites of consuming the news involve a particular ecology of times which interact to produce distinctive temporal experiences which are not necessarily all of a piece. While the temporal logic of fast journalism might indeed dominate in some instances, this can by no means be taken for granted.

As Lefebvre and Regulier explain, our lived experience is shot through with multiple temporalities, but it is in the relationship between them that we experience time (Lefebvre and Regulier 2004: 79). Temporal experience is produced in the ways in which different temporalities rub up against oneanother, and how we navigate the interstitial space between them. So while the idea of timescapes sensitizes us to the analysis of news consumption to multiple temporalities, it remains necessary to account for how we move through the multimediated times of news consumption. Following Bergson, Middleton and Brown emphasise that this is a reflexive process self-consciously experienced in moments of hesitation or belatedness (2010). 
In order to understand how multiple times are reflexively negotiated it is therefore helpful to move beyond the concept of the timescape towards a conceptual framework which can accommodate both the distinctively mediated nature of the temporal ecology of the news audience, and provide a focus on the agentic action of the audience in the production of temporal meaning.

We therefore discuss mediated timescapes of news consumption and the ways in which temporal meanings are produced through the synthesis of their constituent features, as 'zones of intermediacy' (Keightley, 2012; 2013). These are the experiential arenas in which temporal meaning is produced at the juncture of times - embodied, social, cultural historical and technological. While zones of intermediacy are not neatly bounded or fixed in time, they are nevertheless identifiable constellations of times which cohere under particular socio-cultural conditions. Intermediacy opens up to interrogation the multiple layers of media and communications technologies and content that exist alongside the multiple times of social experience. As the social scientific research literature amply demonstrated, contemporary audience experiences of the news are informed by multiple media and are performed in a range of locations. While we cannot simply read off audiences' temporal experience from the temporal logics of media technologies, media texts and technologies are nevertheless crucial constituent elements of them. The news audience is then doubly intermediate, in the sense that its temporalities are produced at the juncture between multiple times, but also in the sense that several of these converging times are those which are those of communications media themselves. In addition the zone of intermediacy is suggestive of an arena in which people act and therefore demands analytical attention to be paid to those who act within it and their navigation and negotiation of manifold times. Zones of intermediacy imply intermediators who realise them.

The notion of intermediacy allows us to acknowledge that the various ways in which we navigate the news might produce a plethora of different temporalities which cannot be captured in a 
one-time model. This is crucial in challenging the assumption that fast news is necessarily a part of the broader desynchronizing and alienating tendencies of technological and social acceleration. Reinstituting an acknowledgement of agency in the production of temporal experience means that we also reopen the possibility for understanding temporal difference as supporting intersubjectivity (Leccardi 2003: 37). News delivers to us 'other times' that we can make proximate (without collapsing into) our own lived times. In this sense even the fastest of media technologies and content generated in a $24 / 7$ news cycle can open up the possibility of more generous, dilated, intersubjective temporal experiences. One distinctive aspect of the bringing-into-relation of different times that is afforded by the news is a temporal relation which occurs across the social scales, with public events and processes being brought into dialogic relation with personal experience. Times of commemoration, the nation, and the collective event are drawn into our own personal sense of time and temporal meaning arises from their synthesis. The bringing into relation of the temporal logic of the news and our own personal temporalities offers opportunities for reflexive positioning of ourselves in relation to not only close relations, but to distant others (Ricoeur 2004: 132). This threefold set of temporal relations between our own experiences as individuals, those whom populate our social lives, and others whose experience we can only access in mediated form produces diverse, reflexive and engaged temporal experiences which cannot be read off from news content or the technologies which deliver it. . Of course, the realisation of agency in the mediated timescapes of news consumption is only possible, and by definition cannot be guaranteed. In order then to demonstrate clearly that acceleration is not always the principle or defining feature of the socially produced times of news consumption we need to turn to precisely the kind of ethnographic data that Bird and Madianou advocate to begin to address what the news (temporally) means in its everyday contexts of use.

\section{Acts of intermediation}


In order to illustrate the ways in which the social practices of news consumption open up zones of intermediacy in which the audience act as active intermediators, active in producing temporal meaning we now draw on two empirical examples. These are both extracts a qualitative diary and an interview conducted as part of the research project Name removed. ${ }^{3}$ This project gathered ethnographic data relating to people's use of vernacular media in everyday remembering practices. As the project unfolded instances of consuming the news featured regularly in people's narratives. It is two such examples that we use here. The examples illustrate that speed and acceleration are not necessarily defining temporal characteristics in the audience's experiences of consuming the news. While neither example relates to online or digital news consumption they illustrate the principle that consuming the news involves multiple times which are actively synthesised to produce temporally inflected meanings. The first example demonstrates how the news features as a constituent element in a zone of intermediacy opened up by another mode of mediated consumption: listening to music on the radio. In the second example it is the act of watching the news that opens up a distinctive zone of intermediacy within which other times are implicated and navigated. It is important to note that by virtue of being produced as part of accounts about media use over a period of time both of the examples are retrospective and none of them refer to social media or mobile devices. In part this is intended as a reminder that 'legacy' media remain crucial in the experience of consuming the news and the attendant temporalities that are produced in the process. Nevertheless, the examples illustrate the mundane ways in which we produce a sense of time using the news, the ways in which these are routinely enfolded into the multitude of times which characterise our experience.

In an extract from a qualitative diary, Helen, a British woman in her late 50s who has recently lost her husband, gives an account of hearing the news of the death of the former British Labour Party leader, John Smith. Whilst the news isn't the starting point of Helen's account it nonetheless illustrates the manifold nature of temporalities of news consumption, its navigation in

\footnotetext{
${ }^{3}$ Emily Keightley and Michael Pickering, 2010-2013. Funded by the Leverhulme Trust.
} 
an everyday context, and the ways in which this produces a dilated social temporal experience in which social relations and identities are constituted.

On a scale of 1-10 of heartache, this morning's music on the radio, a piece from the Hildegard of Bingen collection 'Feather on the Breath of God', plain chant that is the first track, has to score pretty near a 10. I knew it would happen sometime. It was one of our very favourite recordings and one that I already knew and introduced to $M$, on vinyl. It became an early $C D$ in our collection and $M$ even bought copies for his brother and sister for Christmas (I wonder if they ever listen). I have another memory attached to it. I heard it first at the house of a friend of a friend. I had never met her before and knew nothing of her but when we arrived she had this recording playing and I was bowled over. I rang her the following day to get details, I think, but, that day, there was the news that John Smith, the Labour leader, had died and I was upset and actually cried on the phone. She too was sad about it. I know I will have told M about it when I played him the LP.

The temporal constituents of this zone of intermediacy which is constituted in a moment of recollection are numerous. The intermediate zone as we may wish to heuristically delimit it is brought into being through an act of listening to music and the entire zone is structured by the death of her husband: the painful present set off against the pleasurable past brought about by the curtailment of their shared duration. The act of consuming the news in this particular example is folded in to a much broader account of media consumption. Far from the technological time of news dominating the Helen's temporal experience, it is elided in the synthesis of a number of social and mediated times. The zone draws in a number of temporalities. The social time of domestic radio listening in the home is the first identifiable time in play. In her reference to 'this morning's radio' Helen makes reference to the domestic role that radio plays - its implied analogous relationship to the temporal pattern of the day. The radio belongs to the morning as part of her domestic ritual, 
synchronic with lived experience. While the social temporalities of radio imply its repeated ritual role in the structure of a day, the internal structuring of radio content implies dailiness of a different kind. While its organisational structure remains the same (such as the length of each programme, the placing of the news between musical content) these structural features through which content is configured are nevertheless filled will different content which changes each day. So, Helen's sense that her encounter with the painful music 'would happen sometime' speaks to both of all of these times: the knowable routines of the radio programming and their synchronic relation to her everyday lived practices combined with the unknowable scheduling of particular content combine to produce a sense of inevitability and apprehension. This moment of anticipated intrusion of the past in the present is set off against another set of temporal relations related to the repetitious potential of vinyl recordings (which contrast the uncontrollable ephemerality of radio play). This particular piece of music was able to become embedded in the fabric of her relationship with her late husband, not simply at the time that she introduced him to it, but through repeated play it became one of their favourites. Then there is the time of the music itself: the duration of the music opens up the affective space for her to think back over her relationship with $M$ and the immediacy of the experience of musical fidelity in the recoding makes this affectively piercing. At once the time elapsed between the past with her husband and the now of his absence are painfully collapsed and held apart in the process of recollection. Interpolating this experience is the social time of mourning. Helen's account implicates the hesitant forward moves and backward slides in the process of coming to terms with the loss of a partner and she applies her own scale of pain which she has developed in this process to reflect on her progress.

It is in this conflagration of mediated and social times that the distinct times of the news enter the zone of intermediacy. What is particularly interesting about this example is the way in which the technological time of the news media is elided entirely. Instead, in her remark that 'there was the news' that John Smith had died, the news content is assigned temporal primacy. The 
delivery of the news is so embedded in the routines of everyday life the manner of its arrival is literally unremarkable. By saying 'there was the news' Helen signals its synchronic relationship with the everyday, rather than the news arrived which would signal a diachronic relationship. The time encoded in the news content is the politicised time of the Labour Party. The death of John Smith implicates the temporal succession of leaders, and delivers a second punctuating moment of death in the account. This time it is one more explicitly articulated, in contrast to the death of her husband which serves to temporally frame her account in its entirety. The times of the communication of the news and of its content are interpolated further by the sharing of the news with her friend and their common experience of sadness. In specifying that they'd spoken on the phone she introduces the immediacy of a telephonic communication into the account and, at the same time in situating this conversation in the longer-term account of their friendship and its trajectory, she folds this communicative immediacy into the social processes of befriending which occurred over a period of years.

Through Helen's navigation of these multiple times that her own multifaceted temporal experience is produced; one characterised best as a processual coming-to-terms with her profound change in circumstances. In her account she places herself in relation to her husband and the newly delimited nature of the relationship; in a relation of political commonality with her friend; and as part of a broader public narrative of the Labour Party. The media technologies and content at once deliver immediacy and duration - allowing her to bring her autobiographical past into productive relation with public pasts. The temporal logics of the music and of the news at once deliver an experience of immediate knowing (of the death of John Smith) but a durational temporality through which it could be imaginatively experienced and re-engaged with at a later date - an act which at once involves an articulation of her personal relationship with her husband and her own political identity. Overlaid is the synchronicity of the phone conversation through which she brings her own political identity into relation (in this case commonality) with her friend, drawing them together in 
the shared time of a simultaneously public and autobiographical narrative. The temporal affordances of the news media alongside the temporal affordances of the music, radio and telephone allow Helen to at once place and constitute her own sense of herself in relation to both close and distant others.

In the second example Iris, a British woman in her mid-sixties recalls a moment of viewing the nightly news in her account of her everyday media use. In this example it is helpful to provide some additional context. Iris was a from a working class background and had until very recently been employed in domestic services. She had separated from her husband when her daughters were very young in the 1960 s as he suffered from chronic mental health problems. She nevertheless remained as his carer until his suicide in the 1980s. In this extract she recalls watching the televised news of the Aberfan disaster ${ }^{4}$

Iris: The Aberfan disaster, in Wales. I can remember that. Where the slurry went down and covered the village. The school. All the children. I can remember that. I can remember having a Vesta risotto. I can remember when that came on the telly.

Interviewer: What year was that?

Iris: I don't know. The girls were little. I can remember that ever so clear. Interviewer: What made that stick out? Iris: Do you know, I don't know. Interviewer: Do you think about it much? Iris: Sometimes I do. Sometimes I wonder what happened to the village afterwards. But I don't have the telly on much do you.

\footnotetext{
${ }^{4}$ The Aberfan disaster occurred in 1966. A colliery spoil heap collapsed in the Welsh village of Aberfan, destroying a school. 116 children and 28 adults died.
} 
Unlike Helen, where the news is folded in to myriad of other social and mediated times, for Iris the viewing of the news draws in and unites a multitude of other times. She begins her account with the unfolding narrative time of the news story: the location of the disaster, the event and its consequences. The disjointed sentences which characterise her account give some indication of the affective impact of the story. She seamlessly moves between the narrative of the news item and her own domestic lived time: the time of the evening meal which accompanied in ritual fashion the viewing of the night time news. The Vesta risotto is an important historical marker - symbolising not only the first convenience food of the 1960s but marking an autobiographical period for Iris of eating alone after her separation. The authoritative calendar and clock time of the news isn't used to historically locate the story; rather it is historical domestic references to the food eaten at the time and the ages of her daughters. The latter in part explains the resonance of this particular disaster for her at that moment in her life. The clarity of her memory of the news event and its semantic significance arises from this intermediation between news and domestic time.

As in Helen's example, Iris's retrospective recounting of the zone of intermediacy which opened in the act of consuming the news demonstrates that this intermediation of times can facilitate the production and articulation of relationships with distant others and through this produce a sense of commonality (or even communality). The intermediation between the narrative time of news content, the ritual time of viewing the television news combine with an array of historically specific domestic and autobiographical times. It is this intertwining that allows Iris to bring her own lived experience into dialogue with those of others. While Iris's account is limited in the reflexivity it demonstrates, certainly in comparison to Helen, the synchronic relationship between the news and her own social and autobiographical time allows her to articulate empathetic relations with the victims of the disaster, reciprocally constituting her own maternal identity in relation to both her own daughters and to the unknown child victims. More than this, these empathetic relations persist over time as she comments that she sometimes wonders what 
happened to the village. The expansive, critical and social character of this temporal experience stands in stark contrast to the what Hartmut Rosa has called the 'contracted present' facilitated by fast communications

\section{Conclusion}

As Scheuerman notes, the relations between space and time 'structure the horizons of our experience in profound and oftentimes fundamental ways' (2001: 44). While studies of news audiences have addressed the changing relations between space and time in news and journalism, there is little acknowledgement of complex ways in which these changes are locally realised as changes in horizons of experience for audiences. Many accounts of the acceleration of news assume that speedily produced news content and fast, flexible technologies of delivery will necessarily produce temporal experiences which are characterised predominantly by speed and, in many cases, that this will routinely produce superficial engagement with the news, or alienation from it altogether. This article has sought to respond this assumption by writing the audiences back in to our understanding of the temporalities of the news.

In the first instance it is important to state that our analysis doesn't lead us to dismiss speed and immediacy as temporal logics of no concern in assessing the civic functioning of the news media. 24/7 news has profound implications for the quality and quantity of journalistic analysis, just as the immediate communication of smartphone images by witnesses to events poses challenges for photojournalism's long-term engagement with its subject. The significance of these and other consequences of technological speed and immediacy for journalistic practice and news content shouldn't be underestimated. Nor does our analysis suggest that journalistic speed and the immediacy of news have no potential to curtail creative engagement with others or political engagement for audiences. There may well be examples where the temporal logics of news inhibit 
moves between the times of social experience and close down opportunities for constructing relational identities. However, it does demonstrate that the temporalities of news consumption are complex, and not necessarily best understood through the dichotomous pairings of fast and slow, accelerating or decelerating. We need in contrast to pay attention to both the temporality of the news and audience temporalities and their interplay. In neither of the examples presented here do we see an audience which is disoriented, distracted, overloaded or uninterested. Instead we see the folding of the news into the everyday and in the confluence of temporalities that this process involves, opportunities for articulating the relationship between self and other being taken up. It is only when we look at the ways in which the temporal logics of news interact with other media or social times that we can begin to understand the kinds of temporal experiences that they contribute to. In the two examples we have briefly introduced, news time is woven into autobiographical time and made meaningful in the relationship between the two.

We should take care in rushing to judgment about the consequences of acceleration and speed in news production and content for audiences. Immediacy, speed and instantaneity are undoubtedly crucial features of the temporal ecology of news, but when we consider the ways in which these temporal logics enter into vernacular usages of news they are interpolated by a wide range of other times. This is not best understood as a flattening out or collapsing of news time; instead we would do well to consider the novel, interesting and exciting modes of temporal experience that it can support. News audiences do not simply inhabit a journalistic temporality characterised by news production cycles, the media technologies of news delivery or even the extended temporalities of news content itself; rather these are simultaneously navigated by drawing on our own experientially derived temporalities such as autobiographical time, generational time, domestic time or work time. In mediating between and synthesising multiple temporalities, we open up moments of temporal distance and proximity, difference and commonality. While these intermediate temporal zones of news consumption are undeniably contingent, temporary and 
various in their degree of connection with formal political debates, their dilated nature nevertheless provides the conditions for diverse and complex temporal experiences of consuming the news..

\section{References}

Aalberg, T., Blekesaune, A. and Elvestad, E. (2013) Media Choice and Informed Democracy: Toward Increasing News Consumption Gaps in Europe? International Journal of Press/Politics. 18(3): 281303

Adam, B. (1998) Timescapes of Modernity: Environment and Invisible Hazards. London: Routledge.

Adam, B. (2004) Time: Key Concepts. Cambridge, UK \& Malden, MA: Polity Press,

Adam, B. (2008) The Timescapes Challenge: Engagement with the Invisible Temporal.

http://www.cardiff.ac.uk/socsi/resources/Leeds\%20talk\%20prose\%20Timescapes\%20Challenge\%20 250208.pdf

Ahlers, D. (2006) 'News consumption and the new electronic media’. International Journal of Press/Politics. 11(1): 29-52

Berker, T., Hartmann, M., Punie, Y., and Ward, K. J. eds. (2006) Domestication of Media Technology. Maidenhead, Berks: Open University Press.

Bird, S. E (2000)'Facing the Distracted Audience: Journalism and Cultural Context', Journalism 1(1): 29-33. 
Bird, S. E. (2010) in Stuart Allan, ed. The Routledge Companion to News and Journalism Studies. London: Routledge, pp. 417-427.

Bjur, J., Schrøder, K. C., Hasebrink, U.m Courtois, C., Adoni, H. and Nossek, H. (2014) ‘Cross Media Use: Unfolding Complexities in Contemporary Audiencehood' in Carpentier, N., Schrøder, K.C. and Hallett, L. Audience Transformations: Shifting Audience Positions in Late Modernity. Routledge, New York and Abingdon, UK.

Chesnaux, J (2000) Speed and democracy: an uneasy dialogue. Social Science Information. 39(3): $407-420$

Chaffee, S. H. and Metzger, M. J. (2001) The end of mass communication? Mass Communication and Society, 4(4): 365-379.

Cushion, S. (2015) News and Politics: The Rise of Live and Interpretive News, Routledge: Abingdon and New York.

Doane, M. A. (2001) 'Information, Crisis, Catasrophe' in Landy, M. The Historical Film: History and Memory in the Media. London, Athlone Press.

Eurobarometer (2009) Special Eurobarometer The Europeans in 2009, http://ec.europa.eu/COMMFrontOffice/PublicOpinion/index.cfm/Survey/getSurveyDetail/instrumen ts/SPECIAL/yearFrom/1973/yearTo/2009/surveyKy/940

Eurobarometer (2013) Special Eurobarometer 399: Cultural Access and Participation Report 
http://ec.europa.eu/COMMFrontOffice/PublicOpinion/index.cfm/Survey/getSurveyDetail/yearFrom L1973/yearTo/2013/surveyKy/1115

Haddon, L. (2005) ‘Empirical Studies using the Domesticaltion Framework in Berker, T., Hartmann, M., Punie, Y., and Ward, K. J. eds. Domestication of Media Technology. Maidenhead, Berks: Open University Press. pp80-102

Hartmann, M. (2005) 'The Triple Articulation of ICTs. Media as Technological Objects, Symbolic Environments and Individual Texts', in Berker, T., Hartmann, M., Punie, Y., and Ward, K. J. eds. Domestication of Media Technology. Maidenhead, Berks: Open University Press. pp80-102

Harvey, D. (1997) Justice, Nature and the Geography of Difference, Blackwell. Malden, MA and Oxford.

Hassan, R. (2009) Empires of Speed: Time and the Acceleration of Politics and Society. Brill Academic Publishers.

Hassan, R. and Purser, R. E. (2007) 'Introduction' in Hassan, R. and Purser, R. E. (eds) 24/7: Time and Temporality in the Network Society. Stanford, CA. Stanford University Press. Pp.1-24

Huxford, J. (2007) 'The proximity paradox: Live reporting, virtual proximity and the concept of place in the news', Journalism 8(6): 657-674, 
Keightley, E. (2012) 'Making Time: The social temporalities of mediated experience' in Keightley, E. (ed) Time, Media and Modernity. Basingstoke, Palgrave Macmillan.

Keightley, E. (2013) From Immediacy to Intermediacy: The mediation of lived time. Time and Society, 22(1)55-75.

Keightley, E. and Pickering, M. (2014) 'Technologies of memory: practices of remembering in analogue and digital photography'. New Media and Society, 16(4) 576-593.

Ksiazek, T. B., Malthouse, E. C. and Webster, J. G. (2010) News-seekers and Avoiders: Exploring Patters of Total News Consumption Across Media and the Relationship to Civic Participation, Journal of Broadcasting and Electronic Media, 54(4): 551-568.

Le Masurier, M. (2015) 'What is Slow Journalism', Journalism Practice, 9(2): 138-152.

Leccardi, C. (2003) 'Resisting “Acceleration Society”', Constellations. 10(1): 34-41

Lefebvre H and Re'gulier C (2004) The rhythmanalytical project. In: Lefebvre H (ed.) Rhythmanalysis: space, time, and everyday life. London and New York: Continuum.

Lewis, J. Cushion, S. and Thomas, J. (2005) Immediacy, Convenience or Engagement? An analysis of 24-hour news channels in the UK, Journalism Studies, 6(4): 461-477.

Lewis, J. and Cushion, S. (2009) 'The Thirst to be First', Journalism Practice. 3(3): 304-318. 
Madianou, M. (2008). 'Audience reception and news in everyday life', in Karin Wahl-Jorgensenn and Thomas Hanitzsch, eds. The Handbook of Journalism Studies. New York: Routledge, pp. 325-357.

Madianou, M. (2010). Living with News: Ethnography and news consumption. In: Stuart Allan, ed. The Routledge Companion to News and Journalism Studies. London: Routledge, pp. 428-438.

McQuail, D. (1997) Audience Analysis. London. Routledge.

Merleau-Ponty, M. (2002 [1962]) Phenomenology of Perception. London and New York. Routledge.

Middleton D and Brown SD (2010) Experience and memory: Imaginary futures in the past. In: Erll A and $\mathrm{Nu}$ " nning A (eds) A Companion to Cultural Memory Studies. Berlin/New York: de Gruyter.

Nansen, B., Arnold, M., Gibbs, M.R., and Davis, H. (2009) 'Domestic orchestration: Rhythms in the mediated home', Time and Society. 18(2-3) 181-207.

Ofcom (2014) 'Adults' Media Use and Attitudes Report'. http://stakeholders.ofcom.org.uk/marketdata-research/other/research-publications/adults/adults-media-lit-14/

Papathanassopoulos, S., Coen, S., Curran, J., Aalberg, T., Rowe, D., Jones, P., Rojas, H. and Tiffen, R. (2013) Online Threat, But Television is Still Dominant, Journalism Practice, 7:6, 690-704

Peters, C. (2012) 'Journalism To Go', Journalism Studies, 13(5-6): 695-705. 
Phillips, A. (2011) 'Faster and Shallower: Homogenisation, Cannibalization and the Death of Reporting' in Peter Lee-Wright ; Angela Phillips and Tamara Witschge, eds. Changing Journalism. Abingdon and New York: Routledge, pp. 81-98.

Prior, M. (2009) 'The Immensely Inflated News Audience: Assessing Bias in Self-Reported News Exposure' Public Opinion Quarterly 73(1): 130-43.

Reuters Institute (2014) ‘Digital News Report 2014’.

https://reutersinstitute.politics.ox.ac.uk/sites/default/files/Reuters\%20Institute\%20Digital\%20News \%20Report\%202014.pdf

Ricoeur, P. (1985/1988) Time and Narrative: Vol 3. London and Chicago, University of Chicago Press.

Ricoeur, P. (2004) Memory, History and Forgetting. London and Chicago, University of Chicago Press.

Rosa, H. (2008) 'Social Acceleration: Ethical and Political Consequences of a Desynchronised HighSpeed Society' in Rosa, H. and Scheuerman, W. E. (eds) High-Speed Society. Pennsylvania. Pennsylvania State University Press.

Rosa, H. (2010) Alienation and Acceleration: Towards a Critical Theory of Late-Modern Temporality. Malmo, Sweden. NSU Press.

Rosa, H. and Scheuerman, W. E. (eds) High-Speed Society. Pennsylvania. Pennsylvania State University Press. 
Scheuerman, W. E. (2001) 'Liberal Democracy and the Empire of Speed', Polity 34(1):41-67.

Scheuerman, W. E. (2009) 'Citizenship and Speed' in Rosa, H. and Scheuerman, W. E. High Speed Society: Social Acceleration, Power and Modernity. Pennsylvania State University Press, Pennsylvania.

Schrøder, KC (2011) 'Audiences are inherently cross-media: Audience studies and the cross-media challenge' Communication management quarterly, 18(6): 5-27.

Westlund, O. (2015) 'News Consumption in an Age of Mobile Media: Patterns, People, Place and Participation', Mobile Media and Communication. 3(2) 151-159.

Shehata, A. and Strömbäck, J. (2011) ‘A Matter of Context: A Comparative Study of Media Environments and News Consumption Gaps in Europe', Political Communication, 28(1): 110-134.

Silverstone, R. and Hirsch, E. eds. (1992) Consuming technologies: Media and Information in Domestic Spaces, London: Routledge.

Silverstone, R. (1994) Television and Everyday Life, London: Routledge.

Sorensen, K, Aune, M., and Hatling, M. (2000) 'Against Linearity: on the cultural appropriation of science and technology' in Sorensen, K, Aune, M., and Hatling, M., (eds.) Between Understanding and Trust. The Public, Science and Technology. Harwood Academic Publishers.

Sorensen, K. (1994) 'Technology in Use. Two Essays on the Domestication of Artefacts' STS working paper, no. 2/94, NTNU, Centre for Technology and Society: Trondheim. 
Sunstein, C. R. (2007). Republic.com 2.0. Princeton, NJ: Princeton University Press

Tewkesbury 2005

Tomlinson, J. (2007) The Culture of Speed: The Coming of Immediacy. London, Thousand Oaks, New Delhi, Singapore. Sage.

Virilio, P. (1986) Speed and Politics: An Essay on Dromology. (trans. M. Polizzotti) New York: Semiotext(e).

Virilio, P. (1995) 'Speed and Information: Cyberspace Alarm!' http://www.ctheory.net/articles.aspx?id=72

Virilio, P. (2000) Polar Inertia, London; Thousand Oaks; New Delhi. Sage.

Virilio, P. (2006) Negative Horizon, London and New York. Continuum

Webster , J. G.and Ksiazek, T. B. (2012) 'The Dynamics of Audience Fragmentation: Public Attention in an Age of Digital Media' Journal of Communication 62(1) 39-56.

Westlund, O. (2015) 'News consumption in an age of mobile media: Patterns, people, place, and participation', Mobile Media \& Communication 3(2): 151-159

Williams, R. (1992) Television: Technology and Cultural Form, Hanover: Wesleyan University Press. 
${ }^{1}$ See for example Tomlinson 2007; Rosa and Scheurman 2008; Rosa 2010; Hassan and Purser 2007; Virilio 1995, 2000, 2006 